The Journal of Vitaminology 14, 20-27 (1968)

\title{
NUTRITION PROBLEMS AND PROGRAMS IN THE PHILIPPINES
}

\author{
CONRADO R. PASCUAL \\ Food and Nutrition Research Center, National Institute of \\ Science and Technology, National Science Development Board \\ Manila
}

\section{INTRODUCTION}

The Philippines is situated some 600 miles off the Southeast coast of Asia. It consists of 7,200 islands and islets, with its southernmost territorial limits running along $4^{\circ} 30^{\prime} \mathrm{N}$ latitude and its northern limits at $21^{\circ} 20^{\prime} \mathrm{N}$ latitude; from its eastern boundary at $116^{\circ} 55^{\prime} \mathrm{E}$ longitude, it extends westward up to $126^{\circ} 36^{\prime} \mathrm{E}$ longitude. Incidentally, only 2,773 of the above-mentioned islands have been named. Two of its largest islands, Luzon and Mindanao, account for 68 per cent of its total area of 115,739 square miles which is roughly the size of either Great Britain, Japan or Spain. The eleven largest islands make up 97 per cent of the total land area. Being archipelagic, the Philippine coast line totals to 10,850 miles.

The topography varies markedly with mountains, hills and plains being found on nearly all the larger islands. Some mountains rise to about 10,000 feet and there are some 98 volcanoes which are known to be intermittently active. Several rivers provide irrigation and drainage to agricultural lands.

Although the Philippines is in the Tropics and the relative humidity uniformly high, it is generally tempered by constant sea breezes. The average temperature varies within narrow limits, i.e., $26.3^{\circ} \mathrm{C}$ in Laoag and $27.2^{\circ} \mathrm{C}$ in Davao. There are two seasons: The Wet which occurs from June to early November, and the Dry, from late November to May. The rainfall varies greatly from place to place and from season to season due to the effects of prevailing winds and varying topographical conditions. The average monthly rainfall ranges from about 3.4 inches in Zamboanga to 16.8 inches in Surigao.

Of the 29.7 million hectares land area, 27.8 per cent are commercial forest, 2.2 per cent marsh and swamps, with only 37.7 per cent cultivated and other lands. The latter are planted to annual and/or perennial crops, fallowed lands or industrial sites. A total of 7.5 million hectares are used for crop production with 6.1 million hectares being devoted to food crops such as rice, corn, fruits, nuts, etc. and the remainder being given to commercial crops such as coconut, sugar cane, hemp, rubber, maguey, cotton, etc.

As of January 1, 1967, the population is estimated at 34.1 millions. The people are largely of Malayan stock, but there are many ethnographic groups represented. Approximately 85 per cent of the population are Roman Catholics, 10 per cent Protestants, and some 4 per cent Moslems with the latter group being concentrated 
in Mindanao and Sulu.

The population of the Philippines has been steadily rising since 1903. In 1918, with an average rate of population growth of 2.22 per cent, it reached the ten the million mark. The rate of growth rose sharply to 3.06 per cent per year after World War II and so in 1950 or after 32 years, the population has doubled. In 1963 or just 13 years afterwards, another increment of 10 million people came about. At the present rate of 3.2 per cent, the 40 million mark is expected to be reached by 1971, or a 10 million increment being attained after only 8 years.

In 1965 the average population density was 104.2 persons per square kilometer; five years back, the corresponding figure was only 90 . The figure for the Metropolitan Manila area is the highest 29,744 persons per unit area.

The Philippine population is "young" as shown by the total percentages below 15 years of age in Table 1 . It can be observed that the median age has become increasingly lower or younger.

TABLE 1

Median Age and Percentage Distribution of the Population by Broad Age Groups

\begin{tabular}{ccccc}
\hline \hline Age group & 1903 & 1939 & 1960 & 1965 \\
\hline & \multicolumn{3}{c}{ per cent } \\
$0-4$ & 15.1 & 16.3 & 16.9 & 19.0 \\
$5-14$ & 24.1 & 26.7 & 28.8 & 27.6 \\
$15-34$ & 34.4 & 33.9 & 32.9 & 31.9 \\
$35-64$ & 22.9 & 19.6 & 19.2 & 18.8 \\
65 and over & 3.2 & 3.5 & 2.7 & 2.6 \\
Total population & $7,635,426$ & $16,000,303$ & $27,087,685$ & $32,345,000$ \\
Median age & 20.2 & 18.3 & 17.1 & 16.5 \\
\hline
\end{tabular}

There are 87 dialects spoken but Tagalog which is used by around 45 per cent of the people has been chosen as the basis of the national language Philipino being evolved. English, together with a local dialect is used as the medium of instruction in the Philippine schools starting at the primary level. Spanish like Pilipino and English is employed as an official language.

In 1963, the total labor force was estimated to be' 10.3 millions with the total employment at 95.4 per cent. The Philippine economy is based mainly on agriculture. Together with fishing and forestry about 60 per cent of the labor force is employed. However, agriculture as compared with other industries like manufacturing, trade and others has the lowest output. Hence the annual per capita income is only 567 for 1963 (1).

It has been observed that the trend of the already unequal income distribution in the Philippines from 1956 to 1961 was towards more inequality. When compared to the income distribution in the U.S.A., Ceylon, Japan and Malaysia, that of Japan was the least unequal and that of the Philippines most unequal (2).

In a recent report on Philippine health (3) it was revealed that since 1920, the population has increased by 209.7 per cent, and that while the crude birth rate decreased by only 19.6 per cent, the crude death rate was reduced by 60.9 per cent. 
Infant mortality contributed 24.8 per cent of all deaths in 1965 . The fertility rate of 133.4 on the other hand represented an increase of 1.3 per cent over that of 1964. Specific death rate for the 1-4 year age group is 9.9. The five leading causes of death are as follows: pneumonia, 121.2 (per 100,000 population), respiratory tuberculosis 83.4, gastroenteritis and colitis 46.0 , bronchitis 43.1 and diseases of the heart 33.6. Except for the last which has replaced beriberi, the order of the first four causes of death is similar to that of 1964 .

The 1965 food balance sheet of the Philippines (4) showed a total per capita food supply of 1001.7 grams per day which was 2.3 per cent over that of the preceding year. The inadequacy of the available food supply was shown as follows: (a) meat, poultry and fish were sufficient to meet $4 / 5$ of the recommended dietary allowances ; $(b)$ milk, leafy and yellow vegetables and vitamin C-rich foods $1 / 4$; (c) beans $1 / 3$; and $(d)$ eggs $2 / 3$. The attainment of sufficiency in the protective foods especially should be given preferential attention.

Every year since 1965, an average of 4 per cent increase in food production was invariably reported. But inspite of such increases and food importations to augment local food production, the staggering food needs of the rapidly increasing population always overshot the available food supply.

Before we talk about proper nutrition we should see to it that reasonable amounts of the various groups of food area made available to the people. That will then be more practical in the long run to all concerned.

In our effort to assess the nutritional status of our people and at the same time, to recognize and define the nature and extent of our nutrition problems, the Food and Nutrition Research Center undertook nationwide nutrition surveys on a regional basis. Instead of employing only the dietary approach to the problems, clinical examination as well as biochemical tests are included to provide corroborative and/or supplementary data and thus be enabled to have a more definitive assessment of the population's nutriture.

The dietary data for 4 regions in Luzon and 2 in the Visayas are presented in Table 2 and the following may be observed: $(a)$ average food intake is much more deficient in the Visayas than in Luzon; $(b)$ sufficiency is attained only in intake of "cereals" and "other fruits and vegetables"; and $(c)$ the intake of protective foods is in most cases even less than $1 / 3$ of the recommended allowance. The corresponding average per capita nutrient intake obtained from the same regional surveys are shown in Table 3.

It may be noted from the later table that among other facts, the calorie intake is only 76.2 per cent of the recommended dietary allowances and that protein, as well as most of the vitamins are "present" in deficient amounts in the diet.

However, the low calorie intake is very suggestive of calorie under-nutrition in some segments of the population. In view of the said low calorie intake, it is also most likely that some, if not more, of the proteins are being utilized for energy as well, instead of for tissue building and/or repairs alone. This would simply mean that there could be less protein available for growth.

The calcium intake might even turn out to be not deficient at all when requirement for the same is reassessed. The iron intake did not take care of the availability of the mineral in the diet and so the figure could be misleading; the 
TABLE 2

Daily per Capita Food Intake (E.P.) in Luzon and the Visayas, Philippines, Compared to Recommended Allowances

\begin{tabular}{|c|c|c|c|c|c|}
\hline \multirow[b]{2}{*}{ Food Group } & \multicolumn{3}{|c|}{ Per capita food intake } & \multirow{2}{*}{$\begin{array}{l}\text { Recom- } \\
\text { mended } \\
\text { allowances }\end{array}$} & \multirow[b]{2}{*}{$\begin{array}{l}\text { Percent } \\
\text { sufficiency }\end{array}$} \\
\hline & $\begin{array}{l}\text { Luzon } \\
4 \text { regions }\end{array}$ & $\begin{array}{l}\text { Visayas } \\
2 \text { regions }\end{array}$ & Average & & \\
\hline I. Cereals & 342 & 325 & 334 & 318 & 105.0 \\
\hline II. Starchy roots and tubers & 36 & 75 & 55 & 70 & 78.6 \\
\hline III. Sugars and syrups & 24 & 13 & 19 & 33 & 57.6 \\
\hline $\begin{array}{l}\text { IV. Dried beans, nuts and } \\
\text { seeds }\end{array}$ & 10 & 6 & 8 & 20 & 40.0 \\
\hline $\begin{array}{l}\text { V. Leafy and yellow vege- } \\
\text { tables }\end{array}$ & 16 & 18 & 17 & 68 & 25.0 \\
\hline VI. Vitamin C-rich foods & 36 & 17 & 26 & 87 & 29.9 \\
\hline $\begin{array}{l}\text { VII. Other fruits and vege- } \\
\text { tables }\end{array}$ & 120 & 65 & 93 & 94 & 98.9 \\
\hline VIII. Meat, fish and poultry & 79 & 72 & 75 & 108 & 69.4 \\
\hline IX. Eggs & 7 & 3 & 5 & 14 & 35.7 \\
\hline X. Milk and milk products & 38 & 14 & 26 & 168 & 15.5 \\
\hline $\begin{array}{l}\text { XI. Fats and oils including } \\
\text { fats from coconut }\end{array}$ & 10 & 4 & 7 & 29 & 24.1 \\
\hline Total & 718 & 612 & 665 & 1,009 & 65.9 \\
\hline
\end{tabular}

TABLE 3

Daily per Capita Nutrient Intake in Luzon and the Visayas, Philippines, Compared to Recommended Allowances

\begin{tabular}{|c|c|c|c|c|c|}
\hline \multirow[b]{2}{*}{ Nutrient } & \multicolumn{3}{|c|}{ Per capita nutrient intake } & \multirow{2}{*}{$\begin{array}{l}\text { Recom- } \\
\text { mended } \\
\text { allowances }\end{array}$} & \multirow{2}{*}{$\begin{array}{c}\text { Per capita } \\
\text { Intake in } \\
\text { percent RDA }\end{array}$} \\
\hline & $\begin{array}{l}\text { Luzon } \\
\text { regions }\end{array}$ & $\begin{array}{c}\text { Visayas } \\
2 \text { regions }\end{array}$ & Average & & \\
\hline I. Calories & 1,774 & 1,568 & 1,672 & 2,193 & 76.2 \\
\hline Fats $(g)$ & 27 & 15 & 21 & - & - \\
\hline Carbohydrates $(g)$ & 331 & 312 & 321 & & - \\
\hline II. Protein $(g)$ & 47.7 & 45.4 & 46.6 & 54.4 & 86.7 \\
\hline III. Calcium (g) & 0.34 & 0.36 & 0.35 & 1.00 & 35.0 \\
\hline IV. Iron $(m g)$ & 10 & 9 & 10 & 8 & 125.0 \\
\hline V. Vitamin A (I.U.) & 2,097 & 1,700 & 1,900 & 3,772 & 50.4 \\
\hline VI. Thiamine $(\mathrm{mg})$ & 0.84 & 0.76 & 0.80 & 1.19 & 67.2 \\
\hline VII. Riboflavin ( $m g)$ & 0.60 & 0.43 & 0.52 & 1.36 & 38.2 \\
\hline VIII. Niacin $(m g)$ & 15 & 13 & 14 & 12 & 116.7 \\
\hline IX. Ascorbic acid (mg) & 68 & 72 & 70 & 70 & 100.0 \\
\hline
\end{tabular}

Calories are contributed or distributed as follows: 78 per cent from carbohydrates and 11 per cent each from fats and proteins.

same could be said of the vitamin $\mathrm{C}$ intake because the losses due to preparation and cooking of the food have not been taken into account. Thiamine intake may turn out to be adequate when it is considered in relation to the average calorie intake.

The results of the biochemical tests employed in the surveys are summarized in Table 4. It may be noted that the subjects are almost equally distributed among the "low" to "deficient" and "acceptable" to "good" levels of nutriture with respect to hemoglobin and serum vitamin A. Total serum protein levels are mostly in the "acceptable" to "good" levels; and so with that of albumin. On the other hand, 
however, most of the subjects have "deficient" to "low" levels of serum carotene, urinary thiamine and urinary riboflavin.

Mean levels for total serum proteins, serum albumin, serum vitamin $\mathrm{C}$ and serum vitamin A were in the "acceptable" categories; those for urinary thiamine and urinary riboflavin were in the "low". levels, and that for serum carotene, in the deficient level.

Table 5 shows the clinical survey findings and tends to indicate suggestive deficiencies in vitamin A, riboflavin and ascorbic acid, thus corroborating both the dietary and biochemical data. Manifest thiamine deficiency does not appear to be a problem. Except for niacin and iodine deficiencies which are more prevalent in Luzon than in Visayas, the rest of the suggested deficiencies have higher prevalence rates in the regions of the latter.

In general, low levels of nutriture are found even more pronounced, if not more severe among the pre-school children. This could probably be due to the fact that this age-group is a relatively more neglected group than the others and furthermore, they cannot fend for themselves.

Other studies being undertaken in the Philippines are on the chemical composition and nutrient content of raw, cooked and/or processed foods; food processing and/or to make possible fuller utilization of indigenous foods and food

TABLE 4

Mean Value and Percentage Distribution of Biochemical Findings in the Regions Surveyed (4 Luzon regions and 2 Visayas regions)

\begin{tabular}{|c|c|c|c|c|c|c|c|c|c|c|c|}
\hline & \multirow{2}{*}{\multicolumn{2}{|c|}{$\begin{array}{l}\text { No. of } \\
\text { subjects } \\
\text { examined }\end{array}$}} & \multirow{3}{*}{ 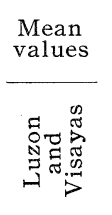 } & \multicolumn{8}{|c|}{ Percentage distribution } \\
\hline & & & & \multicolumn{2}{|c|}{ Deficient } & \multicolumn{2}{|c|}{ Low } & \multicolumn{2}{|c|}{ Acceptable } & \multicolumn{2}{|c|}{ Good } \\
\hline & 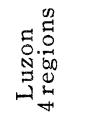 & 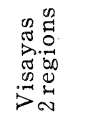 & & 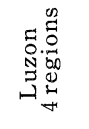 & 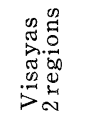 & 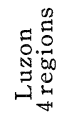 & 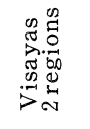 & 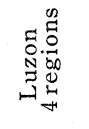 & 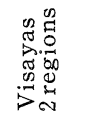 & 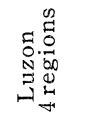 & 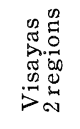 \\
\hline Hemoglobin $(\mathrm{g} / 100 \mathrm{ml})$ & 2,991 & 2,523 & & 11.17 & 12.18 & 45.16 & 36.22 & 23.86 & 24.87 & 19.81 & 26.73 \\
\hline $\begin{array}{l}\text { Total serum protein } \\
\qquad(\mathrm{g} / 100 \mathrm{ml})\end{array}$ & 3,485 & 2,819 & $7.35^{\mathrm{A}}$ & 1.22 & 0.19 & 5.95 & 1.48 & 67.52 & 53.41 & 25.31 & 44.92 \\
\hline Albumin $(g / 100 m l)^{a}$ & 1,378 & 1,867 & $4.13^{\mathrm{A}}$ & 2.61 & 0.96 & 25.83 & 9.90 & 68.76 & 76.98 & 2.80 & 12.16 \\
\hline Serum vit. C $(m g / 100 m l)$ & 3,416 & 2,639 & $0.74^{\mathrm{A}}$ & 21.07 & 31.28 & 26.06 & 28.89 & 29.46 & 22.32 & 23.41 & 17.51 \\
\hline Serum vit. A $(\mu \mathrm{g} / 100 \mathrm{ml})$ & 3,017 & 1,957 & $36.0^{\mathrm{A}}$ & 13.30 & 35.42 & 18.08 & 28.63 & 37.63 & 28.71 & 30.99 & 7.24 \\
\hline $\begin{array}{l}\text { Serum carotene } \\
\qquad(\mu \mathrm{g} / 100 \mathrm{ml})\end{array}$ & 3,092 & 2,006 & $49.0^{\mathrm{D}}$ & 60.89 & 94.06 & 26.08 & 4.70 & 10.66 & 0.94 & 2.37 & 0.30 \\
\hline $\begin{array}{l}\text { Urinary thiamine } \\
\qquad(\mu g / g \text { creatinine })\end{array}$ & 1,661 & 1,206 & $115.0^{\mathrm{L}}$ & 21.61 & 35.44 & 41.99 & 51.35 & 20.43 & 8.18 & 15.97 & 5.03 \\
\hline \multirow[t]{3}{*}{$\begin{array}{l}\text { Urinary riboflavin } \\
\qquad(\mu g / g \text { creatinine })\end{array}$} & 1,656 & 1,211 & $250.0^{\mathrm{L}}$ & 31.23 & 54.36 & 42.50 & 33.38 & 16.18 & 6.43 & 10.09 & 5.83 \\
\hline & & & & \multicolumn{4}{|c|}{ Below 1.1} & \multicolumn{4}{|c|}{1.1 and above } \\
\hline & & & & \multicolumn{2}{|c|}{$\begin{array}{l}\text { Luzon } \\
4 \text { regions }\end{array}$} & \multicolumn{2}{|c|}{$\begin{array}{c}\text { Visayas } \\
2 \text { regions }\end{array}$} & \multicolumn{2}{|c|}{$\begin{array}{l}\text { Luzon } \\
4 \text { regions } \\
\end{array}$} & \multicolumn{2}{|c|}{$\begin{array}{l}\text { Visayas } \\
2 \text { regions }\end{array}$} \\
\hline A/G Ratio ${ }^{a}$ & 1,373 & 1,865 & 1.36 & \multicolumn{2}{|c|}{$52: 34$} & \multicolumn{2}{|c|}{27.84} & \multicolumn{2}{|c|}{47.66} & \multicolumn{2}{|c|}{72.16} \\
\hline
\end{tabular}

${ }^{a}$ Albumin and $\mathrm{A} / \mathrm{G}$ ratio for Luzon includes only 2 regions (Cagayan-Batanes and Southern Luzon) 
TABLE 5

Clinical Signs Suggestive of Nutritional Deficiencies in Luzon and Visayas, Philippines

\begin{tabular}{clcc}
\hline Deficiency & \multicolumn{1}{c}{ Signs } & Luzon & Visayas \\
\hline Vitamin A & Dry conjunctiva & 17.5 & 32.7 \\
& Xerosis & 37.5 & 63.7 \\
Thiamine & Bilateral edema & 0.7 & 02 \\
& Loss of ankle jerk & 0.4 & 0.7 \\
& Loss of knee jerk & 0.2 & 0.5 \\
Riboflavin & Conjunctival injection & 14.5 & 0.8 \\
& Nasolabial seborrhea & 5.5 & 0.7 \\
& Active angular stomatitis & 2.1 & 2.8 \\
Niacin & Angular scars & 27.1 & 56.0 \\
Vitamin C & Papillary changes & 33.2 & 26.7 \\
& Gingivitis (Scorbutic type) & 0.7 & 1.4 \\
Iodine & Margina! gingivitis & 10.5 & 22.8 \\
& Gums, tendency to bleed & 15.5 & 1.0 \\
\hline
\end{tabular}

materials; nutritional evaluation of foods and food materials. Physiologic and anthropometric studies are being given considerable attention at the present time.

\section{THE NUTRITION PROGRAM}

Record of nutrition activities in the country showed that the program started as early as 1900. It consisted mostly of studies done by American and other foreign scientists which were concerned with calculations of food intake of Filipino people and various physiological problems related to nutrition as well as proximate analysis of some Philippine foods. However, the sporadic nature of such undertaking did not gain much headway until after the World the War II when the Institute of Nutrition (now called the Food and Nutrition Research Center) was created in 1947 to expedite the development of an organized program in the country. It was originally assigned to serve among other things as a clearing-house of data and information concerning nutrition. Subsequent statutes have expanded its functions and activities from an emergency program of mass education and information to research, coordination and community organization.

Under the present set-up, the Food and Nutrition Research Center is composed of four divisions which undertake three main activities: Food and Nutrition Researches, Informational Services, and Cooperative and Coordinated Activities.

To further strengthen the efforts at greater involvement of potential leaders in the community, thereby establishing a smoother system for coordinating nutrition work in the country, post-nutrition survey conferences are held in regions where nutrition surveys have been conducted. These conferences serve as a meeting ground for various disciplines from the administrative, supervisory and working levels of member-agencies of the National Coordinating Council on Food and Nutrition as well as civic and private organizations in the region.

A significant result of these regional post-nutrition survey conferences is the subsequent organization of local coordinating councils on nutrition at various 
geographical levels. These councils serve as the implementing group which seeks the realization of action programs developed after the conference.

Another outstanding result of these regional conferences in nutrition was the launching of an applied nutrition project in Bayambang, Pangasinan, whereby an integrated and coordinated program in food production, nutrition education and training and supplementary feeding has been demonstrated. Because of the very promising results realized there, similar projects are being set up in several parts of the country. One of these is in Isabela which is an entirely self-help project, and the two others in Marinduque and Cebu.

\section{THE FUTURE}

It is our hope that in the years to come, more applied nutrition projects will be activated in different provinces in the country, but like the two pilot projects in Isabela and Pangasinan, they should be established on self-help and on an integrated, intersectoral approach after proper sensitization of the people to nutrition in these areas.

There is yet much that remains to be done, no doubt, but what little we have accomplished is due to numberless people doing a lot of things together helping each other because of their deep conviction that these things need to be done to help break the shackles of poverty and disease and economic stagnation.

Hopefully, we pray that in the near future this coordination will spread ${ }^{\text {t }}$ nd involve not only those interested in nutrition within our country but also those of the other parts of the world. If people and its leaders particularly the political and economic leaders can be made to realize the urgency of immediate action towards the solution of our current malnutrition problems, then we can still hope to build a better world, not for ourselves, but for the peace and prosperity of the future generations.

\section{REFERENCES}

1. Belarmino, Isagani C. The Statistical Reporter, 101, No. 3, July-September (1965).

2. Reyes, Peregrino S, and Teresita L. Chan. The Statistical Reporter, 9, No. 7, April-June (1965).

3. Philippine Health Statistics by the Disease Intelligence Center, Department of Health (1965).

4. Food Balance Sheet CY (1965). OSCAS, National Economic Council.

\section{DISCUSSION}

Dr. H. Mitsuda: Your talk is very interesting to me, but I have one question. You mentioned that most vitamins are deficient in the diet of your country. It sounds very curious for me. What happend with Premix rice? On occasion of Unconventional Protein Production Conference held in Santa Barbara last week, I heard from Dr. Milner of UNICEF that Premix rice is nowadays not common in your country. Is it correct? If so, could you tell me about possible reasons for it?

Dr. C.R. Pascual: It is really unfortunate that at this time forces of vested interest has withheld the benifits of rice enrichment from our people. This is due to the economic tie-up between rice enrichment and the milling tax on rice. At the moment home 
enrichment is resorted to by the families instead of enrichment in the rice mills which would have ensured its more generalized use.

Dr. H. Yoshimura: (1) How many grams of protein per kilogram body weight is taken by your people? (2) Have you some protein deficient disease in your country? (3) Please show us the missing figure of average hemoglobin cnotent in your Table 4.

Dr. C. R. Pascual: (1) While the recommendation is $1 \mathrm{~g} / \mathrm{kg}$ body wt., the intake is only $85 \%$ of this recommendation which therefore means that at least protein intake is borderline. Aside from this fact, if we relate this with the low Calorie intake, then it is possible that part of the protein intake is used for energy purposes. (2) Yes, our main deficiency is that of Calories. This is followed by vitamin deficiencies, especially those of riboflavin and vitamin A. Vitamin $\mathrm{C}$ is borderline together with thiamine. We probably have some proteinCalorie malnutrition, esp. in the pre-school age, but this is neither as severe nor as prevalent as in some other countries in this region. (3) Since we do not have a standard for children, we did not report a mean value for Luzon and the Visayas, but we did report mainly for adults as shown in Table 4 for Luzon and Visayas, classifying these into low, acceptable and good, using the approach of the Interdepartmental Committee of the U.S.A.

Dr. C. Kawasaki : I think your recommended allowance for cereals seems to be lower than those in Asian countries. In Japan, $330 \mathrm{~g}$ of rice was rationed per day and now daily intake per capita is estimated to be $350 \mathrm{~g}$. How is your opinion on raising recommended allowance for cereals especially for rice in the Philippines?

Dr. C.R. Pascual: Yes, we realize this to be so, when compared to intakes of rice in other Asian countries. You will note that even with this lower recommendation our actual intake is still lower, showing that either rice is not available for consumption or that it is unavailable to the people because of its high cost. We are intending to increase this somewhat, but then this recommendation must be associated with increased rice production and increased availability to the people.

Dr. T. Oiso: You mentioned in the present paper that there were many races having different languages in the Philippines. Are there any various kinds of taboo or habits which make any difficulty on nutritional education?

Dr. C. R. Pascual: Yes, there are many dialects in the Philippines. Obviously, this poses a problem. One of the ways we try to overcome this problem is to have our talks and our nutrition education materials translated into the local dialects. To some extent the problem solves itself, because most of the younger generations are English speaking so that communication is thus facilitated. As for taboos and habits which affect the peoples nutrition and health there are many. These are generally dealt with in the continuous and persistent nutrition education campaign waged from the village level to the national level. 